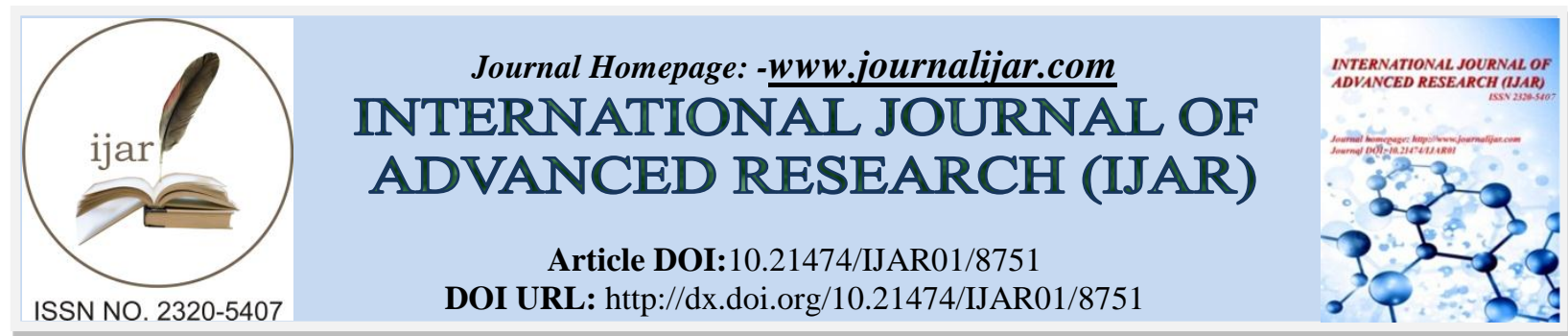

RESEARCH ARTICLE

\title{
USE AREA MERDEKA WALK AS CITY WALK.
}

Suprayitno, Rina Saraswaty and Neneng Yulia Barky. Universitas Medan Area (UMA), Medan, Indonesa.

\section{Manuscript Info}

\section{Manuscript History}

Received: 20 January 2019

Final Accepted: 22 February 2019

Published: March 2019

Key words:-

city parks, open spaces, green city walk, lifestyle, and modern society.

\begin{abstract}
Take advantage of the city park as a round start popping up. This happens to meet the lifestyle of modern society who want to enjoy entertainment while shopping or known city walk In addition, the area of open green land has been reduced due to the development of the city. This research is intended to find out the difference city walk with the public area of the city in general In Knowledge of the lifestyle of community users. In order to find out the role Merdeka Walk Against the lifestyle patterns of society in the development of the city's public space in the use of space. Research site conducted in the field Merdeka Walk As one of the open green space It is the center of Medan city. Research conducted using survey methods, field observations, literature study, and interviews. The external aspect of this research is expected to be an entry point for the relevant parties to maintain the open green spaces and use them as a tourist destination.
\end{abstract}

Copy Right, IJAR, 2019,. All rights reserved.

\section{Introduction:-}

The city has a finite and limited area. The demand for land use in the city will continue to grow, and is akseleratif for various urban development facilities, including the advancement of technology, industry, and transport, as well as changing the natural composition of the Earth/landscape often Urban also confiscated Earth-land and various other open space creations. They are both generally detrimental to the existence Space The open green is often seen as a land reserve and is not economical.

An important spatial city in the effort to efficiently and effectively use the city's resources, as well as natural or other resources. The interdependent and mutually sustainable areas of cities have had a variety of approaches in the planning and construction process. Land use, transport systems, and Network Utility system are the three main factors in determining the space city. In another development, the concept of city space, as well as the major urban problems associated with the search for the solution, are also linked to achieving the ultimate goal of spatial to wellbeing, comfort, and health Residents and the city.

Urban green open spaces have high life benefits. The various functions associated with their existence (ecological, social, economic and architectural function) and the aesthetic value of assets (organisms and environments) can only improve the quality of the environment and the continuity of life Urban but the value of pride and identity can also be to the city. To get open green spaces functional and aesthetic in a wide minimum system, then the urban style and structure, as well as the shape and distribution, should be considered in the establishment and expansion of its scope.

Corresponding Author:-Suprayitno.

Address:-Universitas Medan Area (UMA), Medan, Indonesa. 
The environmental character, the circumstances, and desires of the citizens, as well as the direction and purpose of development and the development of the city, is the main determinant in determining the amount Open green space. and the existence Open green space It is important in controlling the safety and quality of the environment and its preservation. Urban-building control should be proportional and balanced between development and environmental functions.

In carrying out their activities, humans need a place that can accommodate the occurrence of the event. To meet this need but in the context of the commercial space, then one of them by creating open spaces that are safe and convenient that are passed in the middle of the retail space that is now referred to often city walk. The problem is whether city walks Just a new term or have a different understanding with the pedestrian part, pedestrian mall, dan shopping street. Additionally, the public space should be able to be enjoyed by anyone. However, the existence Merdeka Walk It is often felt only towards the middle class economic and on ever. So, see also the important role a city walks as head of the city's public spaces to the community.

This research is intended to find out the difference city walk with the public area of the city in general In Knowledge of the lifestyle of community users. In order to find out the role Merdeka Walk Against the lifestyle patterns of society in the development of the city's public space Use of space in the city.

\section{The theory}

The open space is an area that is planned because of the need for meeting venues and activities together outdoors. Open space, open greenery, public spaces have almost the same meaning. Theoretically, it is open space:

1. The area that works as a container for human life, whether individually or in groups, as well as a bowl of other creatures to live and evolve in a sustainable way (UUPR no.24/1992)

2. A container that accommodates human activity in an environment that does not contain a cover in a physical form (Budihardjo, 1999; 90)

understand about the open green space According to Inmendagri no. 14/1988 the areas within the city or the wider region in the form of region/region as well as in the form of an elongated area/line in its more open use, which essentially without the building that serves as the landscape areas of the city, Forest City, City recreation, sports, agriculture, funeral, Green line and green meadows.

The sense of public space is the space in which all societies can benefit. Main characteristics Public space is: Easily opened by the community to do group activities and not necessarily there must be a green element, the shape is in the form of malls, squares, and playground (Carr, 1992).

According to Aditya W. Fitrianto, city walks Actually no more than the road and devotes the aisle to a row of shops. The difference is, these streets are in your own land-owned developer or managers can be said to be under one roof and the streets allocated to public places. city walk Present in the form of a pedestrian walkway that connects some of the existing commercial and retail functions. The corridor is open (without air conditioning) and a fairly wide range of 6 to 12 meters depending on the types of activities to be created. In addition, city walk as a commercial corridor you should be able to give you a sense of comfort from the tropical climate in Indonesia.

The city is the place where there is a possibility of an environment rich in the lifestyle of the different society. Human beings live, work and enjoy life in social relations and culture. Lynch (1998, hal 5), In his book The Image of The City I found that there are five basic elements used to build a mental image of the city. Any. pathways, districts, edges, landmarks, and notes. The fifth element of the topic expressed above, pathways and notes are the most relevant element city walk as part of the city's public space.

The minimum quality of the public space must be comfortable and safe It can meet the needs of its users. The public space created in areas of the city like the road is one form of the corridor. According to Poerwadarminta (1983) Aisle is the way to get to and out. While according to Kamus Besar Bahasa Indonesia (1990), The corridor is a gallery connecting one building with another. According to Giggert (1959, hal. 100) In the book Town Design The corridors are characterized by three, namely:

1. Shopping street corridor, in this passage, both general, as well as visitors of the vehicle, can move freely in front of the store. 
2. Shopping precinct corridor, A free car across the corridor, or simply the visitor vehicles can enter the corridor with the target to be parked near the shops.

3. Open mall corridor, the circulatory system is completely covered in this corridor. Activities in which more vehicles also occur, usually this corridor also serves as the exhibition space, fashion show, and other activities.

The Road (street) is a corridor in the city or in the village, with buildings on one or both sides, as well as the path of the motor vehicles between the pavement (Funk \& Wagnalls 1985, hal.667). The road has some role, weakening the shape, structure, and comfort of the wearer, as a place of society while people are out and place to meet and socialize, trade exchange, symbolic role, ceremonial, community, and politics is one of the simplest public places as a site for public life

\section{Discussion:-}

\section{Land use change in urban areas}

The city's development, which has rapidly led to the need for urban land, has increased and has often been characterized by changes in land use in urban areas. Land-use change can refer to two things, i.e. land-use change before, or the change in utilization refers to the spatial plan. The changes refer to the previous use of land, a new land use that differs from previous land use, while the change refers to the spatial plan is a new use on the ground is inappropriate with that defined in the spatial zoning plan that passed (Permendagri No.4/1996 On the use of city land guidelines, Psl 1.f).

\section{Type of land-use changes}

The symptoms of land-use change in urban areas consist of some kind of change. Type of land-use changes (Zulkaidi, 1999) Among other things, any

1. Change function (use); Change function is a change in activity types

2. Changes include the intensity of change of KDB, outbreaks, density of buildings, and

3. The technical changes of the building block (bulk) include changes to the boundary line Building (GSB), highrise buildings, and other minor changes without changing the function and that of the Inencesnia.

\section{Factors that cause changes in land use in urban areas.}

Human development experience as well as the development of the city. The city underwent a process of evolution involving the modification of old functions as well as a new function involving adding (Colby; 1959: 287).

Table 1.1:-Factors that cause change Open green space

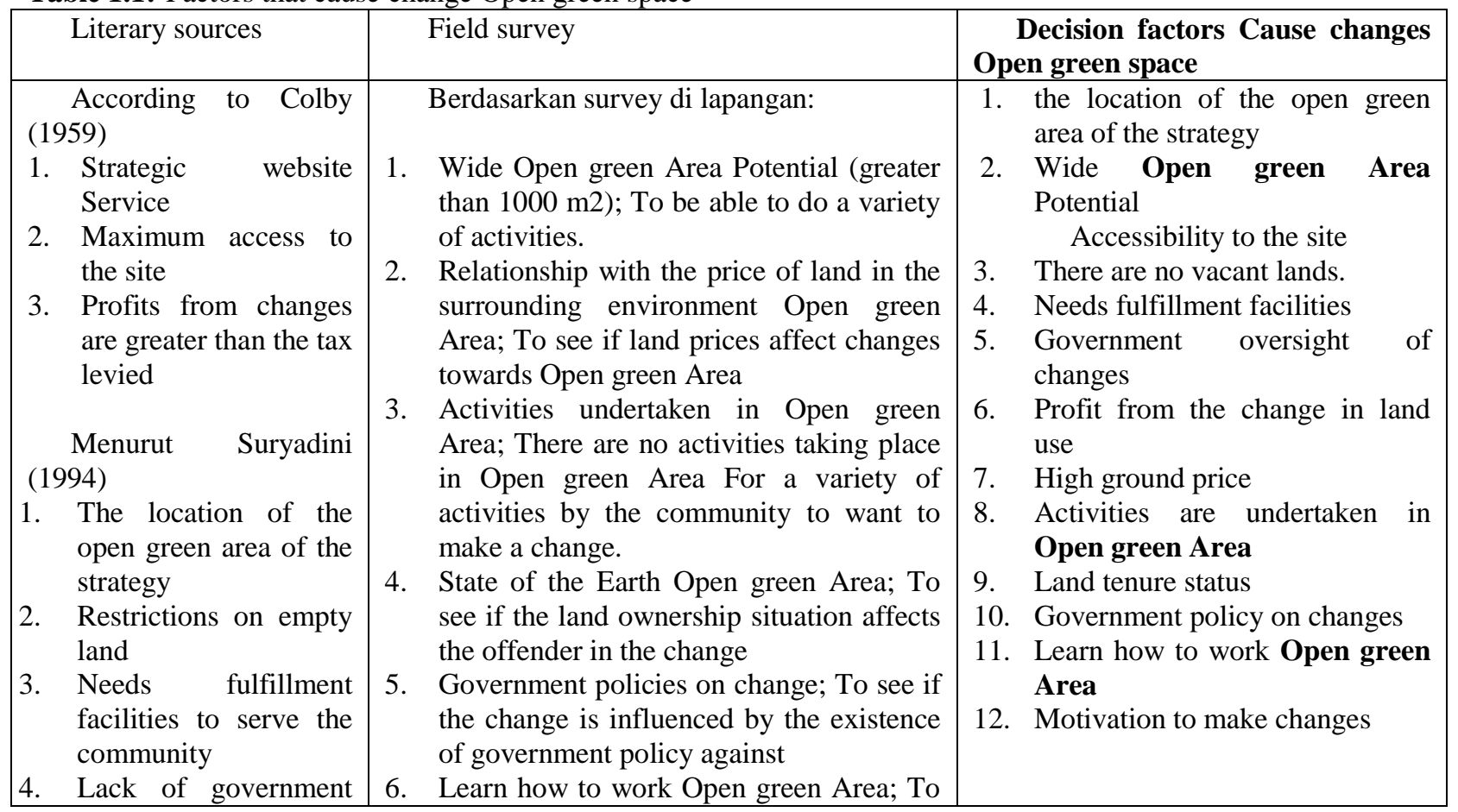




\begin{tabular}{|l|l|l|}
\hline oversight on changes & $\begin{array}{l}\text { view the basics of knowledge will work } \\
\text { Open green Area Effect of making } \\
\text { changes Open green Area } \\
\text { an incentive to make changes; To find out } \\
\text { who became the motive for the unsub to } \\
\text { commit changes to me Open green Area }\end{array}$ \\
\hline
\end{tabular}

\section{Problems posed by the role of the market}

The problem that often arises is that land-use changes are likely to be dominated by the role of the market (market forces) in the development of cities(Kivell, 1993:33).

\section{The problem caused the unsub to develop.}

Changes in land use often lead to disputes between the parties involved; Conflict in the middle is the submission and differences between two or more parties against one or more problems (David, 1995: 246). The party demanded a change of land use Developer usually has the advantage that he will take into account, But often it does not take into account the impact of negative external factors towards the other party and the other party who often suffers from negative externalities/changes in the use of affected lands this is the society, as the city faces, did not Reduce comfort and privacy.

Table 1.2:-Relationship between land use plans and market participants requirements for land-use change

\begin{tabular}{|c|c|c|}
\hline \multirow{2}{*}{$\begin{array}{c}\text { Land } \\
\text { Allocation plan }\end{array}$} & \multicolumn{2}{|l|}{ Land use requests from market participants } \\
\hline & Change & has not changed \\
\hline Change & $\begin{array}{l}\text { Case Type 1a: } \\
\text { There is a change in land allocation to } \\
\text { suit the Earth's changing requirements of the } \\
\text { offender. } \\
\text { Case Type } 1 \mathrm{~b} \text { : } \\
\text { There is a change in land allocation but } \\
\text { not according to the requirements of the } \\
\text { changing land use of the offender }\end{array}$ & $\begin{array}{l}\text { Type } 2 \text { Status: } \\
\text { There is a change in land allocation, but it } \\
\text { does not appeal to offenders who wish to } \\
\text { maintain the use of existing land }\end{array}$ \\
\hline $\begin{array}{c}\text { has } \\
\text { changed }\end{array}$ & $\begin{array}{l}\text { Type } 3 \text { cases: } \\
\text { There are demands for land use change } \\
\text { from the perpetrator that does not comply } \\
\text { with the land allocation (planned) }\end{array}$ & $\begin{array}{l}\text { Case Type } 4 \text { : } \\
\text { There are no requests for changes to land } \\
\text { use or land saving plan changes }\end{array}$ \\
\hline
\end{tabular}

\section{Control of the form of land use changes}

\section{Control of land use according to Pasal 17 UUPR No. 24 years 1992}

Describe pasal 17 UUPR no. 24 years 1992, Control of the use of space is regulated by monitoring and curbing activities aimed at exploiting space and through a mechanism that allows the level region II. Surveillance activities are one of the management tools.

\section{Study City Walk and urban lifestyle in Merdeka Walk Application of case theory against}

Open Cities green space has functioned only as a recreation area, social and cultural, aesthetic, physical, ecological city and has a fairly high economic value for humans as well as for the development of the city, Merdeka Walk It has a variety of plant varieties and other garden tools that can accommodate a wide range of activities. Analyze the function of open green spaces for the descriptive method resulting from field survey and interviews. 


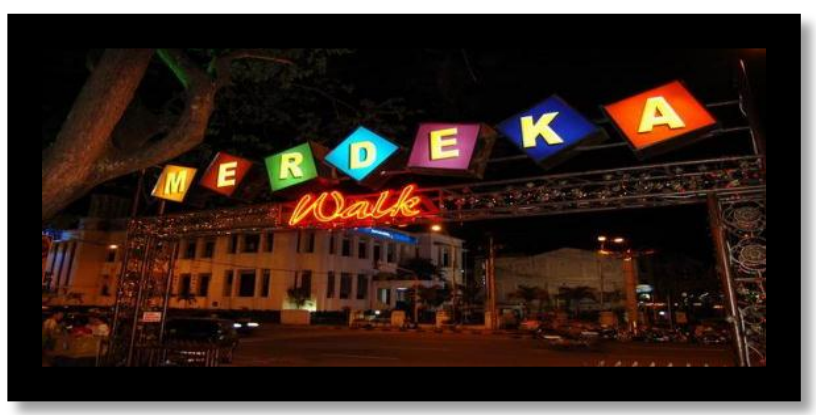

Figure 1:-Merdeka Walk

The Walking Merdeka was founded on the ground $6.600 \mathrm{~m}^{2}$ PT Orange Indonesia supported by the city government of Medan, dedicated to café, restaurant, convention, event, and recreational performances and toys. Merdeka Wok is a center for food, entertainment, and information on the western side of Merdeka Square (City Square), the most strategic in the city center. The Merdeka Promenade will later form a single entity with Hall Town Square and consisted of a five-star hotel that integrates with City Walk, Dili River Cafe and City Hall Club. This concept of the premiere is the first in the field.

The general concept of Merdeka walking is this blend of large café tents is also home to Hawker's food in or open as well as various exhibition activities, promotional activities and entertainment, making the area become the center of the meeting.

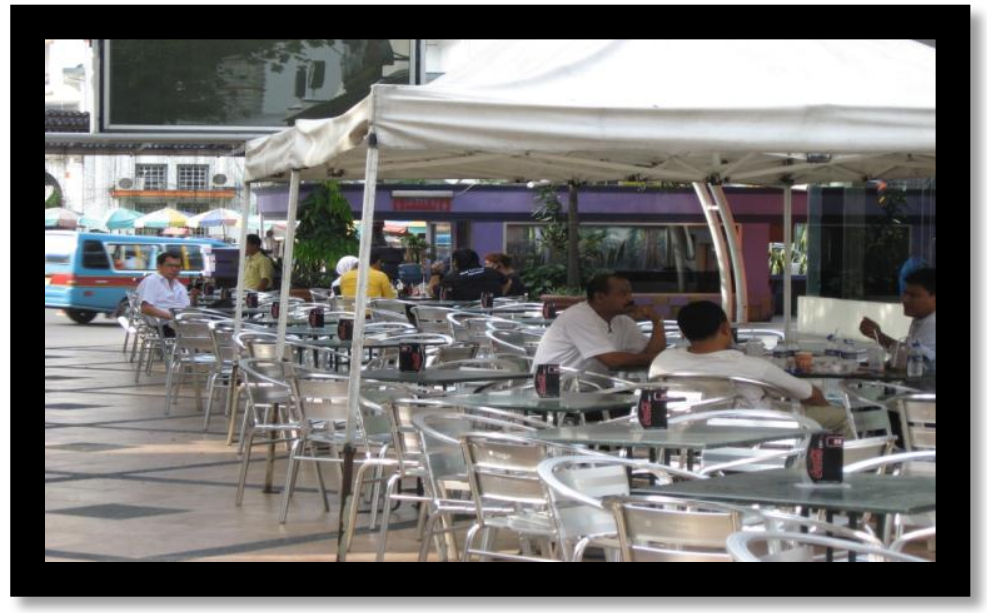

Figure 2:-An atmosphere Poems of Merdeka During the day

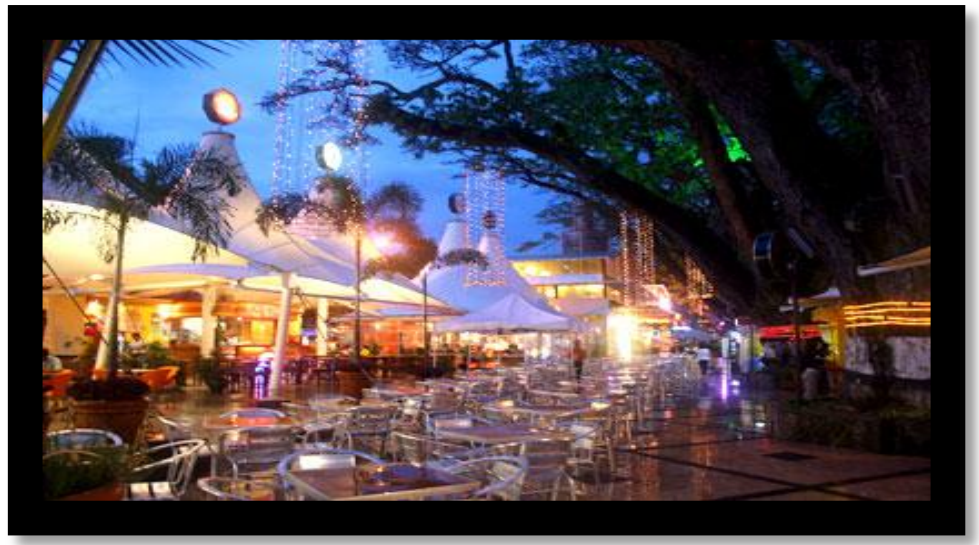

Figure 3:-An atmosphere Poems of Merdeka at afternoon 


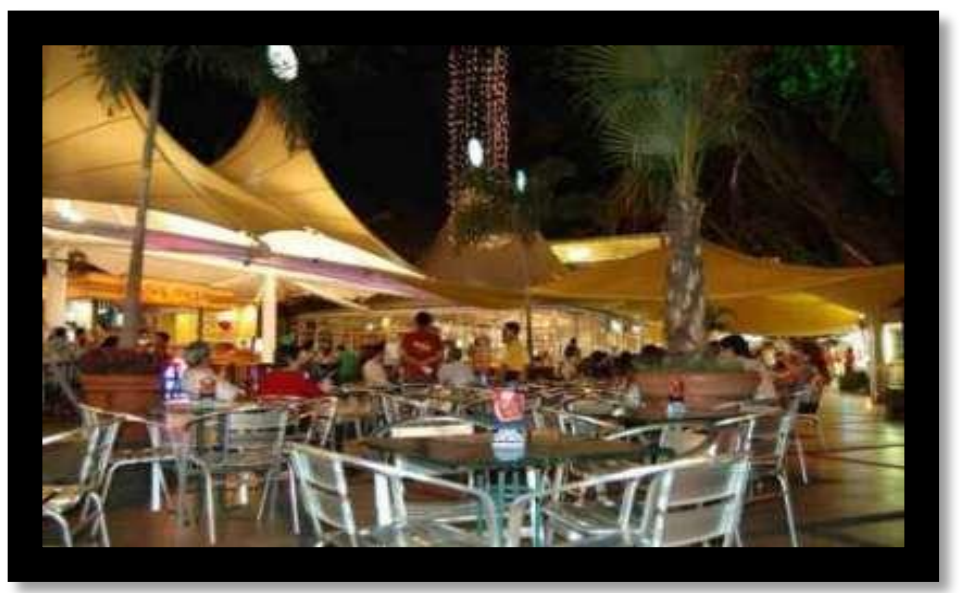

Figure 3:-An atmosphere Poems of Merdeka at night

Walking in the city Located in the form of corridors of open space for pedestrians that link many commercial and retail functions. This corridor is usually open and relatively wide, ranging from 6 to 12 meters, depending on the concept of the type of activity to be created.

Each of them has a slightly different visitor segment so they do not siphon off shopping street visitors, so others are active in the atmosphere and can help to raise the quality of space.

The activity in Walking in the city Usually more towards the lifestyle that is developed at that time. From places to hang out in cafes and restaurants to shops that sell lifestyle related items, such as goods and technology, children's playground, sports, cinema, and handicrafts. This is used with complete success by Merdeka Walk Originally wanted to create a hooker center with special activities opening the arcades. Business Themed Lifestyle Merdeka Walk This has led to becoming one of the favorite places for youth in Medan city. Arcade Intersection Walking in the city It is often used as an open space to display the stage. The function of this activity is useful in inviting visitors at certain times, such as the weekend. In this open space cannot forget to provide a place to sit and the game Environmental graphics Good self-help and the concept Walking in the city It is also expected to be an alternative in an attempt to revive and lift the heart already faded or to keep the old city in the cities of Indonesia to the other.

\section{Summary}

Walking in the city, it can serve as an alternative to the city's public spaces, and provides a safe and comfortable open space, as well as meeting the lifestyle requirements of the city community with the hosts of his activity life on the street so that he is able to raise the quality of the road. Visitors ' activities can fill the gap with shopping, eating and lounging.

Freeing one side of the street as a shopping street from the circulation of vehicles is necessary to make the autonomous region as a walking city walk.

\section{References:-}

1. Aditya W Fitrianto. 2006. City Walk (Ruang Terbuka Alternatif), dalam artikel IAI

2. Budihardjo, Eko, Kota Berkelanjutan, Bandung : Alumni, 1999

3. Funk \& Wagnalls. Funk \& Wagnalls Standart Desk Dictionary. Vol. 2. Funk \& Wagnalls Corporatian. 1984.

4. Gibbert, Frederik, Town Design. London: the Architectural Press. 1959

5. Inmendagri no. 14/1988, Penataan Ruang Terbuka Hijau Di Wilayah Perkotaan, Jakarta, 1988.

6. Lynch, Kevin, The Image Of The City, London: MIT Press, 1998

7. Mardhatilla, Aulia, dkk, Perencanaan Pusat Perbelanjaan dan Ruang Terbuka Pada Koridor Jl. PERMINDO dengan pendekatan Citi Walk, e-journal.bunghatta,

8. Poerwadarminta, W.J.S. Kamus umum bahasa indonesia. 1983. Jakarta : Balai Pustaka.1983.

9. http://images.google.co.id/images?gbv=2\&hl=id\&q=merdeka+walk

10. UUPR no. 24/1992, Penataan Ruang, Jakarta, 1992. 